\title{
MARXISM AND HUMAN RIGHTS: NEW THOUGHTS ON AN OLD
}

\section{DEBATE}

Dr Darren J. O’Byrne

Reader in Sociology and Human Rights

Department of Social Sciences

University of Roehampton

London SW15 5SL

Tel: (020) 83923706

Email: D.Obyrne@ roehampton.ac.uk

Biographical note:

Dr Darren O'Byrne is Reader in Sociology and Human Rights at the University of Roehampton, where he is also director of the Crucible Centre for Human Rights Research. He has published extensively in the areas of the sociology of human rights, globalisation, and critical social theory. His most recent book is Human Rights in a Globalizing World (Palgrave, 2015). 


\title{
Marxism and Human Rights: New Thoughts on an Old Debate
}

\begin{abstract}
This paper revives the debate as to whether Marxism is compatible with a commitment to human rights, but, in presenting a defence of such a compatibility, seeks to extend that debate beyond the confines of philosophical analysis to incorporate the contributions of Marxist theory to the sociology of human rights. It suggests that Marxist theory enables us to re-evaluate the priorities of human rights as a political project, and that in doing so it complements the social constructionist approach prevalent within the sociology of human rights. Taken together, a Marxist theory of social structure and a social constructionist theory of human rights enable a fuller realisation of the possibility of an emancipatory politics.
\end{abstract}

\section{Keywords}

Crisis of Liberalism; Marxism; Marx’s ‘On the Jewish Question’; Social Constructionism; Sociology of Human Rights

\section{Introduction}

Is Marxism compatible with human rights? This is a question many have asked since Marx himself engaged with the then-nascent discourse on human rights in his 1844 essay 'On the Jewish Question' (Marx, 1978). On the one hand, there are those who maintain that the pursuit of human rights is inherently inconsistent with the Marxist project (Buchanan, 1982; Lukes, 1982; 1987). Opposed to this are those who suggest either that a commitment to human rights is at least implicit in Marx's own writings, or that Marxism is a sufficiently broad conceptual framework to incorporate such a commitment while remaining true to the spirit of Marx’s own writings (Bartholomew, 1990; Boyd, 2009; Lacroix \& Pranchere, 2012; Leopold, 2009; McBride, 1984). From the outset, I should make it clear that this contribution is located firmly in the latter camp - I write as an advocate of both human rights and 
Marxian-informed social theory. In presenting my argument, I both build on the existing contributions which pertain primarily to Marxist theory and highlight in addition to those the crucial contributions made by Marxist sociology to our understanding of human rights. It should also be noted that Marxist theory in this sense refers to a broad school of thought comprised of numerous competing, often contradictory, approaches, unified only by their adherence to a defining core set of concepts and values which distinguishes it from other equally broad schools of thought (such as feminism, postmodernism, functionalism and so on). In this sense, Marx's own writings constitute part of Marxist theory, and are thus discussed in depth in the forthcoming argument.

For the most part, the 'debate' in question is not a straightforward either/or binary. The positions advanced by the aforementioned contributors to it differ immensely from one another, not least because many of them are asking different questions, and thus framing the debate in different intellectual terms. In its simplest form, however, it is grounded in two assumptions that have somewhat taken root in 'conventional' Marxist contributions to discussions about human rights: first, that Marx himself must be considered, alongside Hegel, as part of a counter-Enlightenment critique of human rights in general; and second, that human rights must be seen as ideological constructs devised to uphold the interests of capitalism and Western imperialism, i.e. as 'swords of empire'.

It is my contention that these assumptions rely upon narrow understandings at best, and misunderstandings at worst, of both Marxism and human rights. While the first assumption relies upon a very particular reading of Marx's own writings that are in any case inconsistent on the matter, the second betrays a conflation of two distinct points: that human rights intrinsically are 'swords of empire', and that they have become appropriated to become so (Bartholomew \& Breakspear, 2003; O’Byrne, 2016). I would suggest instead that the inclusion of Marxism as a contribution to, rather than a critique of, the theory of human rights 
is essential for both Marxism and human rights: for the former, to rescue it from the dogma of anti-humanist left functionalism, and for the latter, to rescue it from the hegemony of liberalism. In short, I would argue that, as a positive theory of human rights, Marxism can:

(I) Provide a critique of the bourgeois, individualist nature of the dominant liberal tradition in human rights theory (and thus demonstrate the reality of alternative conceptualisations of rights)

(II) As the basis of that alternative conceptualisation, foreground economic and social rights that reflect basic human needs

(III) Promote the struggle for rights as aspirational, i.e. as a counter-hegemonic strategy

(IV) Provide a theoretical framework within the sociology of human rights that understands the relationship between human rights abuses and atrocities, such as genocide, slavery, apartheid, the death penalty and so on, and the protection of capitalist interests.

Though there will be many within the broad Marxist camp who disagree fundamentally on this, it is my belief that none of these contributions to the theory of rights contradicts the most fundamental premise of Marxist theory, i.e. to not only present a critique of but to promote a revolutionary alternative to the capitalist system. The first and fourth contributions listed above clearly form part of the critique of capitalism, the third places human rights discourse in the revolutionary process itself, and the second provides the foundations for an understanding of rights beyond capitalism. It is possible to identify a fifth contribution, which would enable us to redefine which actual struggles count as genuine, and revolutionary, struggles for human rights, those which come directly from the needs, demands and actions of the people rather than the bourgeois elites. Such a contribution would, of course, develop the scope for making demands within a human rights framework, and ally the revolutionary 
project with feminist and/or anti-racist demands. Though I do not focus on that here, largely because to do so would require a degree of empirical engagement beyond the scope of this article, I would maintain that a commitment to it is implicit in the broader argument that follows. (See, among others, Dale and Kyle (2016), Falcon (2016), Gregg (2011, 2016) for contributions to such a debate.)

To demonstrate this broader argument, I will turn first to Marx's actual discussion of rights in 'On the Jewish Question'. This is by no means the only contribution Marx makes to the philosophy of rights, but it is his most influential and most explicit engagement with the subject. In this article, Marx lays the foundation for the first three of these points, but it is the dominant language of rights which he criticises for its individualistic and bourgeois character and a commitment to both the aspirational quality of rights and to a recognition of economic and social rights is in fact central to his argument. I will then survey some of the contributions to the debate on Marxism's relationship to human rights, many of which are clearly inspired by that pioneering article. I will then seek to show how our understanding of the causes of many of the great atrocities and 'crimes against humanity' have benefitted from Marxian analysis, and suggest that, as a theory of human emancipation, the project of Marxism is entirely consistent with the application of a social constructionist theory of rights.

\section{On Marx on Human Rights}

Marx's essay 'On the Jewish Question' is, of course, a commentary on Bruno Bauer's assessment of demands for Jewish emancipation in Germany. By highlighting the anomaly what is so 'special' about Jewish emancipation in a country where nobody is truly emancipated? - he anticipates the 'crisis of liberalism', the clash between equality and the emancipation of a people as a whole community within a nation-state, on the one hand, and recognition of diversity within that state on the other. A significant point of debate within the 
commentary is that the German 'state' was (and is) a Christian state, hence the framing of the debate within the context of the recognition of the (religious) 'Other'. Bauer's response to these demands is that 'we have to emancipate ourselves before we can emancipate others' (Marx, 1978: 28). The anomaly lies in the 'contradiction between religious prejudice and political emancipation' (ibid: 28). Thus, emancipation from religion becomes a condition of political emancipation.

Much of the subsequent analysis of 'On the Jewish Question' has, of course, concerned Marx's apparent attitude towards the Jews in Germany and to Judaism in general, which is not the matter at hand here. Even so, Marx's response to Bauer's argument can be detached from the specific debate (i.e. the 'Jewish question') and understood in more general terms in which case, as Maidan (1987: 28) suggests, he clearly 'endorsed the aspirations of the Jewish community for equality of civil and political rights', not because they are Jews but because they are people who are alienated from their species-being in a capitalist society. For Marx, the emphasis on the abolition of religion detracts from the more significant point, 'the relation between political emancipation and human emancipation' (Marx, 1978: 30). Marx is referring here, of course, to the extent to which in a free state, all particular forms of social distinction, from religion to the possession of private property, must cease to be political concepts. However, they do not then simply cease to exist - rather, they exist in the private sphere, in civil society, where the material life of humankind continues to be lived out (ibid: 34). Significantly, though, Marx is not denying the importance of this political emancipation, which of course provides us with the modern discourse on human rights:

Political emancipation certainly represents a great progress. It is not, indeed, the final form of human emancipation, but it is the final form of human emancipation within the framework of the prevailing social order (ibid: 35 ). 
With this statement, we can interpret Marx's view on full human emancipation, and thus the full realization of human rights, as aspirational, and embedded in a recognition that radical social reconstruction is necessary before these aspirations can be properly realised. The more mature Marx would of course develop this aspirational approach into a systematic critique of capitalism. At this stage in his writings, different tensions are foregrounded, and in distinguishing between the universality and community of the political state, on the one hand, and the diversity and individuality of civil society, on the other, and in recognising the tensions between the two, Marx is again anticipating the modern crisis of liberalism, or 'clash of liberalisms' (O’Byrne, 2016).

Marx thus acknowledges that the demand for civil rights (within the state) is a political act, but an incomplete one: 'If a man ... can be emancipated politically and acquire civil rights, can he claim and acquire what are called the rights of man?' (Marx, 1978: 40). For Bauer, the answer is no, so long as one identifies as a Jew, or a Christian, rather than as a person - 'man has to sacrifice the "privilege of faith" in order to acquire the general rights of man' (ibid). What, then, are these rights, apparently realised in France and in the nascent United States? 'These rights of man,' says Marx, 'are, in part, political rights, which can only be exercised if one is a member of a community. Their content is participation in the community life, in the political life of the community, the life of the state. They fall into the category of political liberty, of civil rights ... It remains to consider the other part, namely the rights of man as distinct from the rights of the citizen' (ibid: 41). At this point, it could be argued that, despite obvious differences, Marx is anticipating the trenchant critique of the newly institutionalised discourse on human rights presented by Hannah Arendt (1951) in the aftermath of the Second World War. 
These freedoms of the individual, which today, perhaps confusingly, fall under the heading of political rights (in a use of the term 'political' that is somewhat at odds with Marx's), include freedom of conscience and religion and of ownership of private property. These are, for Marx, misleadingly articulated as 'rights of man' (i.e. human rights), in many major constitutions and declarations (1978: 41), just as they are the innate 'natural rights' according to the liberal political philosophy of John Locke. Thus, famously, these so-called 'rights of man' are the rights of 'egoistic man' separated from others and from the community (ibid: 42). This is the anomaly of these 'rights' - that they are all, in the last instance, defined by the concept of liberty and thus to self-interest (the separation of 'man' from 'man'), such that equality becomes little more than the right to equal liberty, and security becomes little more than the protection of one's liberty (ibid: 42-43).

For Marx, then, the political revolution, the dissolution of civil society into its crudest atomistic components, is an incomplete revolution. The dislocation of those civil rights from the wider political community in which each person is a citizen in abstract reflects not a realization of 'human nature' (as liberals since Locke would have us believe) but a negation of it.

Legal covenants and conventions which purport to protect these rights continue to uphold this fallacy, the separation of rights into distinct categories ('civil', 'political', 'economic', 'social', 'cultural' and so on) and the prioritization of some over others. This is of course the ideological character of the discourse of human rights. Yet as social constructionists, about whom I will say more below, insist, rights are part of an unfinished, permanent revolution, demands born out of historically specific struggles. This is not at all incompatible with the point that Etienne Balibar (2013), following Claude Lefort (1986), makes, that human rights are constantly being 'invented' in struggles against previously unrecognised tyrannies, and that the politics of human rights is in their naming rather than their upholding. Marx 
anticipates this and hints at the potential realization of 'human rights' in the reunion of the individual and society. The full articulation of this comes, of course, elsewhere in Marx's writings wherein the 'human' is embedded firmly within the material conditions of existence. It is precisely this - the recognition of what we now refer to as economic and social rights that is missing from the declarations and constitutions Marx criticizes. With apologies to George Bernard Shaw, one "cannot talk the "rights of man" to someone with bodily hunger in his eyes'.

\section{On the Compatibility of Marxism and Human Rights: An Evaluation of the}

\section{Debate}

The underlying question, of course, is whether Marxism can provide us with a theory of human rights. In reviewing the literature related to this question, Amy Bartholomew (1990) has usefully shown how it might be rephrased in three distinct ways. First, following Steven Lukes (1982, 1987), ‘can a Marxist believe in rights?' Second, following Drusilla Cornell (1984), 'should a Marxist believe in rights?' Third, as preferred by Bartholomew herself, 'should a Marxist believe in Marx on rights?'

On whether a Marxist can believe in rights - or, to put it more accurately, whether a commitment to rights is consistent with Marxist theory - Steven Lukes (1982, 1987, 1993) clearly thinks not. Residents of his mythical Proletaria reside in a land beyond the need for such rights, comforted by the wisdom of an ideological guru who, in phrases carefully selected by Lukes, 'described talk of them as "ideological nonsense" and "obsolete verbal rubbish"' (Lukes, 1993: 29). It is certainly true that Marx used such aggressive language, and more besides, when dismissing rights-talk in his polemic against socialist revisionism, Critique of the Gotha Programme (Marx, 1938). Yet even in Lukes's ostensibly hostile account, there is a recognition that it is the language of rights that is redundant in the utopia 
of Proletaria, where the intent of this language has been fully realised. No doubt for Lukes, Marxists view human rights in much the same way as they view charity - as a response to the inherent contradictions of capitalism that not only becomes irrelevant when capitalism is overthrown but which serves the ideological function of sustaining the flawed system in the first place. If we follow this logic, then Marxism is not only incompatible with human rights in theory but also in practice, even when used to protect the most vulnerable members of society that Marxism ostensibly stands for.

Such a logic follows a somewhat limited reading of both Marxist theory and of the philosophy of human rights, and, in Bartholomew's assessment, presumes not only that there is a singular Marxist doctrine, but that adherence to it necessarily excludes normative questions. The confusion arises from the assumption that human rights equate to freedoms that are antithetical to the Marxist tradition, to socialist or communist political systems. Of course, as Cohen (1995) conveniently reminds us, the juxtaposition of socialism to liberalism in respect of the negation or promotion of freedom as an absolute value is itself problematic, given that the very 'freedom' espoused by the advocates of the liberal tradition is relational, i.e. bound up in a set of social relations, and therefore false. Some are rich precisely because some are poor, and vice versa.

This point has been picked up by Paul Blackledge in his contributions to the debate (Blackledge, 2008, 2012). Blackledge's underlying thesis is that Marx's theory does not equate to a critique of morality per se, but, rather, a critique of bourgeois morality, which underpins contractarian, utilitarian and Kantian theories of ethics in equal measures. First and foremost this manifests itself as an uncritical acceptance of the belief in the separation of individual and society. Marx's critique of this is not merely a critique of individualism, but of the ahistorical assumptions of liberal theories of ethics, which of course come to the fore in theories of human rights as natural rights. The liberal theory presupposes both the absolutism 
of individualism and the certainty of material scarcity, and from these assumptions come the foundations of capitalism - indeed, they serve to reinforce the belief that capitalism is inevitable. Blackledge reads Marx as an 'historical humanist' who, in applying a historical, contextual and relational approach to the problem, debunks such myths. Marxism, and socialism more generally, is inherently compatible with certain aspects of the Kantian project (from which much of the modern discourse of human rights derives): for both, the goal is freedom, but for Marx, liberals simply misunderstand what freedom means. Marxism is thus able to liberate humanist moral theory from the liberal, capitalist agenda - or, to put it another way, to liberate a 'true' understanding of rights from its specific bourgeois variant.

A Marxian ethical theory can therefore present us with a distinctive and meaningful theory of human rights. Human rights, like Marxism, is not a singular discourse, as many still believe, and even if it was in Marx's day, is no longer reducible merely to these exalted individualistic civil and political freedoms (Boyd, 2009: 585). Indeed, the modern recognition of social and economic rights is itself almost unthinkable without the contributions of Marx (Van Herpen, 2012: 11). In his contribution to one of the most important volumes ever published on the theory and practice of human rights, Sergius Hessen distinguishes between 'socialism' as an extension of liberalism, committed to the promotion of positive rather than negative liberties, and 'communism' which is born more directly from Marx's maxim of wealth redistribution (akin to Lukes's Proletaria). Accordingly, a socialist theory of rights embraces two distinct types of rights: first, those positive freedoms such as the right to work or to education (1949: 118), and second, those 'economic rights' to be free from exploitation which derive from the Marxian concept of species-being, the person-as-producer (ibid: 120-121). Under communism, according to Hessen, the essence of these rights would no longer be embedded merely in specific social relations (such as in the workplace) but in the general social relations of society itself (ibid: 124-127). However, Hessen maintains that the latter is merely 
a constituent of the former, 'not a higher and more distant ideal than that of socialism, but only a technique of the realisation of the rights of man' (ibid: 127).

Such a realisation of rights, for Hessen, necessarily contradicts the liberal emphasis on freedom of consumption (ibid: 127-128). Even so, in Hessen's formulation, socialism, in its various forms, can best be understood as an alternative means of ensuring rights by rethinking rather than entirely negating them, even if, in its more extreme form, it demands a suspension of rights in the process of achieving the full realisation of liberty as an indivisible state of being (ibid: 133). Hessen thus reads Marx - and the Marxian doctrines of the Soviet leaders - as entirely sympathetic to the promotion of the 'rights of man'. While there is clearly no ambiguity in respect of the Marxist critique of this freedom of consumption, i.e. the 'right' to private property, since Marx and Engels explicitly addressed the issue in the Communist Manifesto, the extent to which this necessarily renders Marxism hostile to the concept of liberty is certainly open to debate. In the same volume, John Somerville suggests that the liberal and socialist conceptions of rights might actually be complementary, and that the path of world history might lead to a reconciliation of the two (1949: 152). While this may not be a direct contribution to the debate over the compatibility of Marxism and human rights, it does serve to remind us that at the outset of the modern 'age of rights', in the postwar era, 'human rights' was a contested discursive terrain, not yet treated as synonymous with the values of Western liberalism. More recently, in their comparison of the respective emancipatory projects of Marx and Human Rights Watch, Gordon, Swanson and Buttigieg leave open the possibility that the apparent incompatibility between the Marxist and liberal projects is superficial and that the application of insight from the former might help to 'complete' the latter (Gordon, Swanson \& Buttegieg, 2000).

If we return to Bartholomew, we should recall that her preferred alternative to the rather rigid question posed by Lukes was whether a Marxist should believe in Marx on rights? She 
suggests that, even if Marx himself was dismissive of the idea - and that is by no means a certainty - it may still be incumbent on those who profess to be Marxists to champion it. Indeed, she goes further in suggesting that not only is Marxism not incompatible with a commitment to rights, but that such a commitment is perhaps central to the Marxist project. Bartholomew reads Marx himself as having been broadly supportive of citizens' rights, which locate the individual within the political community, and not entirely hostile, at least in principle, to those individualistic, personal rights (the 'rights of man') which he criticised for separating the individual from the community (1990: 250). Though Marx stands proud as a critic of the liberal concept of freedom, nowhere in his critique does he explicitly deny the necessity of these civil, political and intellectual freedoms which are expressed as rights (Roth, 2004: 41). Rather, she argues, Marx's objections were to the execution of these rights in the service of bourgeois ideology, to the prevalent form of rights talk (ibid: 253). She concludes that, if we concede that Marx was not as hostile to the idea of rights per se as some would have us believe, his error was in failing to recognise the importance of them in achieving the 'rich individuality' central to the socialist project (ibid: 254-255).

This oversight seems, to an extent, understandable. Marx's more explicit writings on rights were produced while he was still in the process of constructing his general theory of market society, at a time when he was primarily concerned with how market society results in alienation from species-being. Bartholomew may be correct to suggest that Marx was not inherently hostile to the idea of the 'rights of man', recognising them as progressive to an extent, but his hostility towards the 'right' to ownership of private property, upon which he believes other rights are grounded in the declarations and constitutions of his time, is, as I have already acknowledged, undeniable. Not that the critique of property rights, of course, is unique to Marxist theory, as any reader of Proudhon will know. It is the direction Marx takes this critique in, within the formulation of his broader theory, that is distinctive. In the 
evolution of Marxian thought, alienation transforms into commodification, a concept which is inconceivable without some understanding of the exploitation of rights-talk. Even in these earlier writings, it is clear that, for Marx, the concept of rights prevalent in market society is one derived from commodification - these are not human rights but consumer rights, and they remain firmly rational, perhaps even just (Lacroix \& Pranchere, 2012: 442), within the capitalist mode of production. In contemporary market society, we are witnessing first-hand how the rampant trend towards unrestricted commodification results in a proliferation of demands couched in the language of rights (O’Byrne \& Bond, 2014), which serves only to dilute the concept and alienate it from any political, emancipatory significance.

Commodification necessarily negates rich individuality, and it negates human rights.

This, perhaps, is the most important point to consider - more important, for sure, than whether Marx himself disapproved, in theory and in practice, of the language of rights, as he surely did. Marx's critique is grounded in a reasonable and entirely consistent critique of the possessive individualism implied by the language of rights. However, the difference, for Marx, between the individualistic 'rights of man' and 'citizens' rights' (or political rights) is not merely a categorical distinction between civil and political rights as types of rights, but relates to the politicisation of civil rights, i.e. the raising of such rights as freedom of expression beyond the level of abstract individualism (according to which the rights-bearer is little more than a demanding consumer) and into the realm of the shared political community (wherein the consumer becomes a citizen). In this sense, the project of Marxism is not only compatible with, but intrinsically bound up with, the project of establishing a framework of political rights where those rights are conceived as participatory rather than abstract (Boyd, 2009: 586). Herein lies the truth of Marx's position on, and critique of, 'natural rights'. 


\section{On Marxism as a Contribution to the Theory and Sociology of Human}

\section{Rights}

These debates pertaining to the relationship between Marxism and human rights have been well-rehearsed over the years, although there is always mileage in revisiting them from a fresh perspective from time to time. What is often lacking, however, in such discussions is an engagement with the sociological literature relevant to the study of human rights that draws heavily on Marxist theory. To some extent this is understandable. The sociology of human rights is itself a relatively new sub-discipline (or, more to the point, has only been recognised and named relatively recently). It is not my intention here to go into the reasons for this, or to reflect once again on whether there is a contradiction between sociology and human rights (but see O'Byrne, 2012, for a defence of the sociology of human rights). I will explain more about what I perceive to be the benefits, and the most appropriate conceptual framework, of a sociology of human rights in relation to Marxist theory below. But even before such a field as the 'sociology of human rights' had been identified and thus contested, Marxist sociologists were carrying out extremely informative studies of very real human rights problems and concerns, and the absence of any acknowledgment of this in the largely philosophical literature on Marxism and human rights is disappointing at best.

Consider, for example, the sociological literature on slavery. Notwithstanding the fact that Marx and Engels presented their own sociological account of slavery as a social institution in The German Ideology (Marx and Engels, 1970), or that slavery, as a pre-capitalist mode of production, is a crucial aspect of the Marxist theory of historical materialism, there has been a rich tradition of Marxist and neo-Marxist sociological theories of slavery since at least the 1960s. While writers such as Geoffrey Ste Croix (1981) and Tom Brass (1999) have largely concentrated on slavery in historical perspective, drawing explicitly on historical materialism, 
others such as Eugene Genovese $(1965,1971)$ have developed a broader Marxian-informed sociological account of the relationship between slavery and capitalism. As a system of oppression which serves to subjugate the workforce and stall the process of proletarianisation, slavery can be understood not only as a pre-capitalist mode of production but as an articulation of the complex capitalist mode, or social formation. Indeed, that there has been considerable debate as to whether the North American slave systems constituted a precursor to, or a particular articulation of, the capitalist mode, or perhaps a bit of both, a precapitalist system within a broader global capitalist economy, is itself testament to the richness of the Marxist contributions to this field. Genovese's own contributions, which draw heavily on the ideas of the pre-eminent Italian neo-Marxist Antonio Gramsci in demonstrating how the master-slave power dynamic operates as a hegemonic process that both reinforces and is reinforced by capitalist interests, have been crucial to this, but decades earlier the sociologist Oliver Cromwell-Cox (1948) was presenting a convincing account of how racial and racist ideologies, upon which slavery, apartheid and similar forms of segregation are grounded, are themselves structured through the economic base of society in order to reinforce capitalist ideology.

Consider also the corresponding literature on genocide, not least Sartre's association of genocide with colonialism and, by extension, capitalism, which is clearly in the Marxist tradition via Lenin's theory of imperialism. Sartre (1968) reads genocide - or at least certain examples of genocide - as the outcome of 'total war' for scarce market resources made necessary by capitalism's expansionist urge. In his analysis of the atrocities committed against the Aboriginal communities of Australia as part of the British colonial project, Tony Barta (1987) has expanded upon this by locating the drive towards genocide firmly within the social relations of capitalist society. Indeed, capitalism's inherent systemic tendency towards genocide enables Barta to differentiate between a genocidal state and a genocidal society. 
Martin Crook and Damien Short (2014) have applied a similar logic in their more recent research on the causes of ecocide. In researching the genocidal and ecocidal atrocities committed against the indigenous populations of Australia and Canada, these authors make explicit use of a Marxian framework to connect ecological imperialism with the latest, most destructive stage of global capitalism - work of this kind has its origins, of course, in Marx's own critique of the commodification of nature in the capitalist mode of production.

These examples and others demonstrate the usefulness of Marxism in achieving a fuller understanding of the realities of human rights abuses and struggles. That is to say, they make use of Marxist theory to explain the structural conditions which give rise to these abuses and struggles, which is a distinctly sociological rather than philosophical concern. It is not a stretch to extend this form of analysis to other practical human rights concerns - for example, how the death penalty is disproportionately applied to the poorest communities who cannot afford private legal representation, and serves to reinforce both the class system and the broader capitalist ideology. It seems somewhat disingenuous to state that, whatever Marx may have thought about 'human rights' in the abstract sense, he stood in bitter opposition to the particular atrocities, including slavery and the death penalty, that give the most cause for concern to the modern human rights movement, regardless of whether this opposition was framed within Marxist theory. The problem raised by Lukes and others, of course, is whether Marxism as a theoretical framework can provide a foundation for a theory of human rights in this abstract sense. As we have seen, opinion is divided on the matter. However, even if one concludes, with Lukes, that it cannot, it does not follow that Marxism cannot present us with a theory of human rights in a different sense, a meta-theory of rights which stands in opposition to the dominant liberal tradition. Marxists have not been alone in criticising the essentialist, foundationalist discourse of human rights advocated by the liberals.

Communitarians of various political persuasions have been engaged in a similar task for just 
as long, or perhaps longer. More recently, sociologists have taken up the mantle by identifying the sociology of human rights as a distinct and meaningful body of knowledge (to which many of the writers mentioned above can be listed as precursors or at least fellow travellers). Under the banner of social constructionism, sociologists have sought to treat rights not as pre-social absolutes, but as articulations of desires framed within a politicised and emancipatory language (O’Byrne, 2012). The language of human rights thus becomes a heavily-contested terrain.

That 'human rights' means not a set of legally proscribed entitlements, which are in any case highly relative and subjective, but a general principle grounded in some concept of human dignity or worth, of people as ends-in-themselves, in the Kantian sense, is at the heart of this social constructionist perspective. There is no denying that Marx explicitly shared this belief (Lacroix \& Pranchere, 2012; following Leopold, 2009: 153-155), and it is entirely consistent with the points made by more contemporary commentators, such as Lefort and Balibar, on the on-going process of inventing and defining rights.

From such a perspective, it becomes apparent that human rights, far from being dismissed as the ideological tools of the bourgeoisie, constitute an artillery for use against the very forces of oppression that Marxism stands in opposition to. This is evident regardless of whether rights as philosophical concepts are compatible with Marxism as a political project. Also, echoing a point made earlier in our brief discussion of Bartholomew, given Marx's explicit condemnation of such atrocities, it is evident regardless of whether Marx himself was inconsistent in failing to recognise the progressive potential of human rights as defences against oppression (Van Herpen, 2012: 10-11). It is with this in mind that one might operationalise the Marxian-informed analysis of the death penalty suggested above, or a similar application in respect of the disproportionate and political use of censorship or torture. It is also with this in mind that an anthropologist or sociologist might champion the 
application of a 'bottom-up' approach to the articulation of rights-discourses by a local NGO or civil society group while remaining firmly within the boundaries of the broader Marxist tradition. Or, to put it another way, "defending rights (which recognise the need for the protection of people against unequal forces) can sit comfortably alongside the aim to rid the world of the need for rights by removing the foundational problem of inequality" (Boyd, 2009: 589).

Precisely how this is achieved, and how this apparent compatibility is received, is not always clear. Gordon, Swanson and Buttigieg (2000) interrogate the campaigning work of Human Rights Watch through the lens of Marxist theory, and suggest that the ostensibly emancipatory project undertaken by the human rights organization is actually incapable of achieving its own goals precisely because it fails to address two crucial Marxist insights, the socioeconomic conditions within which rights violations occur, and the ideological nature of law. However, there remains a tension between the advocacy of a rights-based approach and a structural diagnosis of global inequality. As Boyd (2009: 582) acknowledges, much contemporary Marxist use of human rights discourse is merely convenient rhetoric. Rightsdiscourse effectively becomes a practical tool, a means-to-an-end rather than an end in itself. Indeed, it can be argued that Marx himself embraced rights merely as pragmatic instruments of struggle (Van Herpen, 2012: 17). From a different perspective, Hannah Miller (2010) has demonstrated something similar in her observations on the left-leaning anti-global poverty NGO War on Want, which she suggests has adopted a 'rights-based approach' in some of its campaigning without submitting wholly to an ideological commitment to rights-discourse, which it associates with liberalism.

Part of the issue at stake here is not so much whether Marxism is compatible with human rights but whether the Marxist left is willing to identify with the human rights movement. Its possible reluctance to do so may in part be due to the latter's association with the 'rainbow 
coalition' of new social movements and thus with the 'politics of identity' which, as Eric Hobsbawm (1996) and others have stressed, has always been at odds with the universalism of the Marxist project. This seems somewhat disingenuous, though, if we acknowledge that the universalism of the human rights project is equally at odds with the politics of identity and that it is precisely this contradiction that has resulted in the contemporary crisis of liberalism (O’Byrne, 2016). Even so, whether or not a Marxist (or Marxist-oriented) individual or organisation fully embraces a commitment to human rights or conveniently appropriates it for the purpose of the struggle, it is difficult to deny the importance of the aspirational power of human rights to the Marxist emancipatory cause. The struggle for equality and social justice in an inherently unequal and unjust capitalist system, for the personal autonomy and positive freedom of each individual to flourish regardless of her or his place in the relations of production, is entirely appropriately framed as a struggle for rights, and in this sense, the achievement of human rights which are absolute and unconditional becomes a legitimate strategic goal of the revolution. The concept of human rights has tremendous symbolic power. Nowhere is this power more fully recognised than in the writings of the sociologist Leslie Sklair (2002).

Sklair's contribution to the debate is distinctive because he approaches it not from the perspective of either the philosophy or sociology of human rights, or indeed of Marxist theory per se, but from an attempt to provide a sociological understanding of the contemporary process of capitalist globalisation. Nonetheless, in doing so, he makes a bold claim not only for the compatibility but for the necessity of socialism and human rights as an integrated project. Sklair asserts that the dominant form of what is commonly referred to as 'globalisation' is distinctly capitalist in character, a process of economic liberalisation and market deregulation that benefits the corporations and the transnational capitalist class at the expense of the rest, the hegemony of which is sustained by a culture-ideology of 
consumerism. Following Gramsci, and recognising that it is not 'globalisation' per se that is inherently capitalist but its dominant form, Sklair makes the case for an alternative 'socialist globalisation' of which human rights forms the culture-ideology. By positing the idea of human rights as a counter-hegemonic strategy in opposition to consumerism, Sklair is explicitly embracing the revolutionary potential of human rights in a manner far removed from those more 'traditional' Marxists who would happily dismiss them and talk of them as 'swords of empire'.

\section{Conclusion}

In this paper, I have revisited the somewhat complex debate on the relationship between Marxism and human rights from the perspective of a sociologist concerned with understanding the structural and normative conditions within which rights-claims are made. While it has been my assertion throughout that the absence of any direct engagement with the sociological literature has left this debate somewhat lacking, it is nonetheless apparent that any such engagement would further strengthen the position to which I am sympathetic. While Steven Lukes has made the clearest statement in respect of the incompatibility of Marxism and human rights, his argument is grounded primarily in a very specific, canonical reading of the principles of Marxist philosophy - i.e. that there is a theoretical inconsistency between the two. Even if this is true, it is not at all inconsistent to apply a Marxian conceptual framework to an analysis of human rights practice, as Gordon, Swanson and Buttigieg do in their assessment of the work of Human Rights Watch, or as Cromwell-Cox, Genovese, Sartre and Barta do in their evaluations of racial segregation, slavery and genocide. But it seems possible, even likely, that a more assertive position might be advocated, in which a commitment to the values of Marxism presupposes a commitment to human rights, albeit via a critique of the dominant liberal perspective, and that a commitment to human rights would be enhanced by a commitment to Marxism. 
This clearly involves a careful interrogation of what is meant by 'human rights'. In a Marxist sense, as implied by Marx himself, rights are neither 'universal' or 'foundational' as they appear to be in the liberal tradition, as this surrenders to the fallacy of possessive individualism, nor are they conditional and dependent as they are for legal positivists and other relativists. Rather, they are relational, embedded in intersubjective social relations. This, in fact, places Marx squarely in the tradition that flows from Kant to Rawls and Habermas, of which sociological social constructionism is a derivation. Thus, the compatibility between Marxism as a theory of society and social constructionism as a metatheory of rights is a logical one, while the compatibility between Marxism as a theory of society and human rights as an emancipatory political discourse is not only logical but practical and, as Marx himself would perhaps agree, consistent with the desires and aspirations of the progressive socialist activist.

In addition to presenting us with such a constructionist and relational theory of rights - one which is not unduly tainted by either of the twin demons of universalism or relativism - the major contribution of a Marxian theory is in its ability, contra liberalism, to locate these rights within the context of a class-divided society, particularly in so far as the political and legal institutions of such a society necessarily serve the interests of the dominant class (Roth, 2004: 52). In its inability to facilitate change from unequal social relations and oppressive power dynamics, liberalism, despite its claims of neutrality, is inherently conservative (ibid: $65)$.

I would, then, close by restating what is necessary, and distinctive, about a Marxist theory of rights, as outlined at the beginning of the paper. The primary concern of any social constructionist sociologist of rights is to demonstrate how human rights as a discourse is not reducible to any proscribed list of guarantees or entitlements, and thus not synonymous with any single attempt at such a proscription, i.e. the liberal tradition which declares rights to be 
particular freedoms of the individual. Marxists effectively heed the social constructionist battle-cry by reclaiming the language of rights as a general discourse and presenting within that discourse an alternative conceptualisation of it in which the needs and demands born out of the material conditions of existence are prioritised, these being framed then as economic and social rights. The desire for, commitment to and achievement of these rights is crucial to the broader political struggle, as Sklair and others demonstrate, and the negation of these rights in practice cannot be properly understood, and therefore challenged, without an understanding of those material conditions in which such oppressive practices take place, and of the interests such practices serve.

\section{Word Count: 7125}

\section{Acknowledgments:}

I would like to thank Martin Crook and the anonymous reviewers for casting their critical eyes over an earlier draft of this paper and making invaluable suggestions.

\section{Bibliography}

Arendt, H. (1951) 'The "Rights of Man": What are They?' in The Origins of Totalitarianism New York: Harcourt Brace

Balibar, E. (2013) 'On the Politics of Human Rights' Constellations Vol. 20, No. 1, pp. 18-26 Barta, T. (1987) 'Relations of Genocide: Land and Lives in the Colonization of Australia' in I. Wallimann \& M. Dobkowski (eds) Genocide and the Modern Age New York: Greenwood Bartholomew, A. (1990) 'Should a Marxist Believe in Marx on Rights?' in Socialist Register pp. 244-264

Bartholomew, A. \& Breakspear, J. (2003) 'Human Rights as Swords of Empire' in Panitch, L. \& Leys, C. (eds) The New Imperial Challenge London: Merlin Press 
Blackledge, P. (2008) ‘Marxism and Ethics’ International Socialism No. 120

http://isj.org.uk/marxism-and-ethics/

Blackledge, P. (2012) Marxism and Ethics: Freedom, Desire and Revolution New York:

SUNY Press

Boyd, C. (2009) 'Can a Marxist Believe in Human Rights?' Critique Vol. 37, No. 4, pp. 579600

Brass, T. (1999) The Political Economy of Unfree Labour Cambridge: Cambridge University Press

Buchanan, A. E. (1982) Marx and Justice: The Radical Critique of Liberalism Totowa, NJ:

Rowman \& Allenheld

Cohen, G. A. (1995) Self-Ownership, Freedom and Equality Cambridge: Cambridge

University Press

Cornell, D. (1984) 'Should a Marxist Believe in Rights?' Praxis International Vol. 4, No. 1, pp. $45-56$

Cromwell-Cox, O. (1948) Caste, Class and Race New York: Doubleday

Crook, M. \& Short, D. (2014) 'Marx, Lemkin and the Genocide Ecocide Nexus'

International Journal of Human Rights Vol. 18, No. 3, pp. 298-319

Dale, J. \& Kyle, D. (2016) 'Smart Humanitarianism: Re-Imagining Human Rights in the Age of Enterprise' Critical Sociology Vol. 42, No. 6, pp. 783-797

Falcon, S. M. (2016) Power Interrupted: Antiracist and Feminist Activism Inside the United Nations Seattle: University of Washington Press

Genovese, E. (1965) The Political Economy of Slavery New York: Vintage 
Genovese, E. (1971) In Red and Black: Marxian Explorations in Southern and AfroAmerican History London: Allen Lane

Gordon, N., Swanson, J. \& Buttegieg, J. A. (2000) 'Is the Struggle for Human Rights a Struggle for Emancipation?' Rethinking Marxism: A Journal of Economics, Culture and Society Vol. 12, No. 3, pp. 1-22

Gregg, B. (2011) Human Rights as Social Construction Cambridge: Cambridge University Press

Gregg, B. (2016) The Human Rights State: Justice Within and Beyond Sovereign Nations Philadelphia: University of Pennsylvania Press

Hessen, S. (1949) 'The Rights of Man in Liberalism, Socialism and Communism' in UNESCO (ed.) Human Rights: Comments and Interpretations New York: Columbia University Press

Hobsbawm, E. (1996) 'The Universalism of the Left' New Left Review No. 21, May/June, reprinted in M. R. Ishay (ed.) (1997) The Human Rights Reader New York: Routledge Lacroix, J. \& Pranchere, J-Y. (2012) 'Karl Marx: Fut-il vraiment un opposant aux droits de l'homme?' Revue francaise de science politique Vol. 62, No. 3, pp. 433-451

Lefort, C. (1986) 'Human Rights and Politics' in The Political Forms of Modern Society Cambridge, Mass: MIT Press

Leopold, D. (2009) The Young Karl Marx: German Philosophy, Modern Politics and Human Flourishing Cambridge: Cambridge University Press

Lukes, S. (1982) 'Can a Marxist Believe in Human Rights?' Praxis International Vol. 1, No. 4, pp. $334-345$ 
Lukes, S. (1987) Marxism and Morality Oxford: Oxford University Press

Lukes, S. (1993) 'Five Fables About Human Rights' in S. Shute \& S. Hurley (eds) On Human Rights New York: Basic Books

Maidan, M. (1987) 'Marx on the Jewish Question: A Meta-Critical Analysis' Studies in Soviet Thought Vol. 33, No. 1, pp 27-41

Marx, K. (1938; orig. 1875) Critique of the Gotha Programme New York: International Publishers

Marx, K. (1978; orig. 1844) ‘On the Jewish Question’ in R. Tucker (ed.) The Marx-Engels Reader New York: Norton \& Co.

Marx, K. \& Engels, F. (1970; orig. 1845-46) The German Ideology New York: International Publishers

Marx, K. \& Engels, F. (1985; orig. 1840) The Communist Manifesto New York: Penguin McBride, W. (1984) 'Rights and the Marxian Tradition' Praxis International Vol. 4, No. 1, pp. $57-74$

Miller, H. (2010) 'From 'Rights-Based' to 'Rights-Framed' Approaches: A Social Constructionist View of Human Rights Practice' International Journal of Human Rights Vol. 14, No. 6, pp. 915-931

O’Byrne, D. J. (2012) 'On the Sociology of Human Rights: Theorising the LanguageStructure of Rights' Sociology Vol. 46, No. 5, pp. 829-843

O’Byrne, D. J. (2016) Human Rights in a Globalizing World London: Palgrave O'Byrne, D. J. \& Bond, C. (2014) 'Back to the Future: The Idea of a University Revisited' Journal of Higher Education Policy and Management Vol. 36, No. 6, pp. 571-578 
Roth, B. R. (2004) 'Retrieving Marx for the Human Rights Project' Leiden Journal of International Law No. 17, pp. 31-66

Ste Croix, G. (1981) The Class Struggle in the Ancient Greek World London: Duckworth

Sartre, J-P. (1968) On Genocide Boston: Beacon Press

Sklair, L. (2002) Globalization: Capitalism and Its Alternatives Oxford: Oxford University Press

Somerville, J. (1949) 'Comparison of Soviet and Western Democratic Principles, with Special Reference to Human Rights' in UNESCO (ed.) Human Rights: Comments and Interpretations New York: Columbia University Press

Van Herpen, M. H. (2012) 'Marx and Human Rights: Analysis of an Ambivalent Relationship' Cicero Foundation Great Debate Paper No. 12/07 